sciendo Порівняльна професійна педагогіка 9(4)/2019 Comparative Professional Pedagogy 9(4)/2019

DOI: $10.2478 /$ rpp-2019-0039

Postgraduate Student, ARTEM ZAIKA

Oleksandr Dovzhenko Hlukhiv National Pedagogical University Address: 61 Putivlska St., Hlukhiv, Sumy region, 41400, Ukraine

E-mail: zaikaartem44@gmail.com

\title{
FORMING DIGITAL LITERACY IN STUDENTS BASED ON THE EXPERIENCE OF EU COUNTRIES
}

\begin{abstract}
The article analyzes the tendencies in the development of digital literacy of citizens of European Union member states in educational institutions. The urgency of the study is driven by the need to develop the skills needed to communicate effectively in the epoch of 4 - the Industrial Revolution. This study focuses on analyzing the approaches needed to build digital literacy, as well as identifying its key development criteria in the education systems of the UK, Slovenia, the Netherlands, Lithuania and Estonia. Attention is drawn to the existing documents and programs that formulate conceptual trendsways for digital literacy across Europe. At the same time, in the European Union there is no common model that reflects the ways and methods of digital literacy, each country defining its priorities for achieving the goals. It is noted that digital literacy is characterized as one of the key skills for developing the professional competencies of a teacher and a competitive specialist. Based on the study of digital literacy experience abroad, it is possible to define a clear public policy focused on high levels of digital literacy and digital skills. The digitalization status of educational establishments and the population of Ukraine, which is defined as low, is compared. The main directions of the concept of development of the digital economy and society of Ukraine for 2018-2020 are described which aim to bridge the "digital divide" in comparison with the developed EU countries. It is concluded that it is precisely the educational institutions need significant reform. Based on the analysis of digital literacy approaches abroad, this study identifies priority areas for reforming education systems in the European Union in line with current labor market and digital society requirements.

Keywords: digitalization, digital literacy, digital competence, digital technologies, digital education, forming methods.
\end{abstract}

\footnotetext{
АНОТАЦІЯ

У статті аналізуються тендениії розвитку цифрової грамотності громадян крайн членів Свропейського Союзу в закладах освіти. Актуальність дослідження зумовлена потребою у формуванні умінь та навичок, потрібних для ефективної комунікачії в епоху 4 - промислової револючії. У даному дослідженні особлива увага приділясться аналізу підходів необхідних для формування цицрової грамотності, а також розкрито ї̈ ключові критерії розвитку в системах освіти Великої Британії, Словенії, Нідерландів, Литви та Естонії. Звертається увага на наявні документи та програми що формують конщептуальні напрями набуття цифррової грамотності, які сумісні для всієї Європи. В той же час в Свропейському Союзі не існує загальної моделі, щуо відображає иляхи та методи формування ичифрової грамотності, кожна краӥна визначає свої пріоритетні напрями досягнення иілей. Зазначається, щуо циифрова грамотність характеризується як одна з ключових навичок для формування
} 
sciendo Порівняльна професійна педагогіка 9(4)/2019 Comparative Professional Pedagogy 9(4)/2019

професійних компетенцій педагога та конкурентоздатного фахівия. На основі дослідження закордонного досвіду формування цифрової грамотності можна визначити чітку державну політику орієнтовану на високий рівень оволодіння громадянами иифровою грамотністю та навичками користування цифрровими технологіями. Порівнюється стан циирровізації закладів освіти та населення України, щзо визначається як низький. Описані головні напрями концепції розвитку ичифрової економіки та суспільства Украӥни на 2018-2020 метою яких є подолання «цифрового розриву» порівняно з розвиненими краӥнами ЄС. Зроблено висновок, щзо саме в заклади освіти потребують суттєвого реформування. Це дослідження дозволяє на основі аналізу закордонних підходів формування ичифрової грамотності визначити пріоритетні напрями реформування систем освіти краӥн Європейського Союзу відповідно до сучасних вимог ринку прачі та цичфрового суспільства.

Ключові слова: ицирровізація; ичифрова грамотність; ичфрова компетентність; цифррові технологї̈; цицррова освіта; методи формування.

\section{INTRODUCTION}

The development of digital technology is so rapid that it is evident in every person's daily life. But the active use of digital technology in the training of today's highly qualified specialist has only been observed in the last decade. It is in our time the process of digitization of society has become intensive. The notion of "digital literacy" and its derivatives has been formed recently in the scientific world, but the formation of digital literacy as a key component of the digital competence of the specialist, in the epoch of digital economy, is now the main task in the professional education of developed countries and Ukraine.

For a long time, the concept of digital literacy was considered only in the context of the educational process, but because of the impact of digital technology on all spheres of human life, it became necessary to form digital literacy of all members of society. For example, the digital economy, on the one hand, creates the need to train a modern specialist who has professional competencies in the field of digital technologies, on the other hand, for the citizens of all countries, it is a question of having a common digital literacy, which will allow intensive and productive use of digital technologies for their own needs (selfrealization, work, rest, study, leisure of everyone), as well as for achievement and realization of common economic, social and public goals (Kovalchuck, 2017a; 2017b).

Foreign authors have been discussing digital literacy since the second half of the twentieth century, while domestic scholars have been actively studying the issue only for the last decade.

As noted by researchers L. Thomas and Stommel in the context of the digital world and the globalization of education, the value of digital standards is increasing. They are a guarantee that educational recepients will be able to complete training prepared for the labor market and be able to contribute to society. Teachers and educational leaders will be able to take advantage of digital technology in their professional work (Stommel, 2014).

\section{THE AIM OF THE STUDY}

The papers analyzes the international experience of forming digital literacy of citizens and defines their importance for the functioning of society under the conditions of mass spread of digital technologies.

\section{THEORETICAL FRAMEWORK AND RESEARCH METHODS}

The problem of the introduction of digital technologies in the educational process is devoted to the work of such domestic and foreign scientists as N. O. Aristov, 
M. I. Zhaldak, O. M. Spirin, O. V. Malykhin, N. V. Morse, V. Yu. Bykov, M. F. Birka, V. V. Lapinsky, V. I. Kovalchuk, O. V. Spivakovsky, A. P. Yershov, V. M. Monakhov, V. G. Razumovsky, I. O. Novik, A. I. Poplavsky, L. N. Khutorska and others. It is worth noting that the study of this problem by the above authors has an important impact on the formation and development of digital competence (Kovalchuck, 2018). Along with the legal justification for updating the conceptual apparatus of education, in particular in the direction of its digitization, there is a scientific understanding and interpretation of a number of definitions. Foreign authors D. Belshaw, B. Hirsch, G. Creeber \& R. Martin, L. Manovich, J. Stommel and others.

If we consider the concept of digital literacy as interpreted by D. Belshaw in his book "The Essential Elements of Digital Literacy", he points to the existence of different models of this phenomenon and distinguishes eight major components of human interaction with digital environment: cultural, cognitive, constructive, communicative, isolated, creative, using of analytical and digital content assessment skills, civic component of life (Belshaw, 2011). As a contemporary cultural phenomenon the concept of digital culture is also analyzed by foreign scientists C. Bassett, C. Gere, G. Creeber, M. Deuze, R. Martin, M. Hand, usually compare it with new media. According to C. Gere's apt phrase, digital technology is a marker of the culture of the last decades, it includes both artifacts and communications, and features typical of the modern lifestyle (Gere, 2008).

The development of digital literacy is one of the most important conditions for the development of any digital economy in any country, as it is closely linked to all spheres of society and economy. Digital skills are also considered to be a prerequisite for the development of all other priorities in the area of harmonization of the EU and EaP digital markets identified at the ministerial level meeting on the topic "Digital Community" (The European Commission, 2017).

Therefore, based on the Association Agreement signed with Ukraine and the European Union, the main goals of Ukraine's development are the gradual integration into the priority directions of development of the digital society of Europe. Among these areas is the initiative "Digital Agenda for Europe", which sets digital society priorities within the Europe economic growth strategy "Europe 2020: A strategy for smart, sustainable and inclusive growth" (Digital Agenda of Ukraine - 2020).

Based on European norms, the concept of development of the digital economy and society of Ukraine for 2018-2020 has been developed, measures are taken to implement appropriate measures for digitization of the economy, public and social spheres, awareness of the existing challenges and instruments for development of digital infrastructures, acquisition of digital competences by citizens, identifies major digital industries for stimulating the internal market for the production, using and consumption of digital technologies (Cabinet of Ministers of Ukraine, 2018). The research methodology included descriptive methods (study, analysis and description of documents, scientific and educational sources) and comparative method (identification of common and distinct pedagogical patterns).

\section{RESULTS}

The most common mechanism of forming digital literacy in society is educational programs aimed at digital literacy in the period of getting education and various courses that aimed at adapting society to the conditions of digitalization. At present, national policies on digitization vary significantly across countries.

The UK's education reform is going underpinned by the major development trends outlined in the Digital Agenda for Europe, an economically forward-looking developing of the country that is heavily focused on current digital technologies. 
sciendo Порівняльна професійна педагогіка 9(4)/2019 Comparative Professional Pedagogy 9(4)/2019

In accordance with the UK Digital Strategy 2017 targets (UK Parliament official site, 2017), the 2018 EdTech strategy has been developed to identify seven key digital literacy approaches:

1. Digital Teaching Professional Framework (DTPF), which structures and defines relevant digital skills in the education sector, develops and implements digital professional learning standards.

2. EdTech Teacher Status (EdTechTS) is prepared on the basis of the "Professional Digital Learning Framework" to ensure and support the effective and progressive development of digital literacy for teachers, trainers and administrators in education.

3. Accessible learning - introduction of various forms of digital literacy enhancement, motivation for stable personal development in this area.

4. EdTech Training Association is committed to enhancing innovative scientific research and creating a community to share digital experience through collaboration and global networking opportunities.

5. Developing of digital literacy - providing training in developing the skills of applying the latest digital technologies, developing digital products and encouraging them to use constantly and motivate to develop their own digital literacy steadily.

6. Sharing experiences - improving access to content that provides informational support and motivates members of the digital community to increase the level of user skills that drive digital development and implementation.

7. Specialized educational services - the inclusion of educational services in the main areas of grant investments, as well as the formation of financial flows aimed at the development of digital technologies and products involved in the educational process.

Due to the great attention of the UK Government, the number of advanced training programmes and training courses is steadily increasing and being updated in line with the introduction of innovative digital technologies and labor market requirements (UK Parliament official site, 2017).

Important educational areas that reflect the role and place of the digital educator in the Netherlands include the "Onderwijs 2032" online platform aimed at organizing and supporting the learning, engagement and development of digital skills through developing basic digital skills and digital literacy. The participants and users of the "Education 2032" e-platform are constantly in the process of discussing the development of innovative content for the future, focused on the development and dissemination of new curricula (Ons onderwijs 2032, 2016).

An important document characterizing the trends in the use of digital technologies in the educational sector of the Netherlands is the "Technology Compass for Education 2019-2020", developed with the support of the Kennisnet Foundation. Kennisnet Foundation experts focus on educating digital literacy educators, which will enhance the use and application of digital technologies to achieve their goals. They determine that the using of cloud computing technology is one of the major current tendencies that will affect at the educational process over the next five years (IT competency framework for teacher).

Of interest is the practice of Slovenia, which is undergoing a transformation of digital society. According to the Digital Economy and Society Index (DESI) for 2017 (an index that summarizes European digital performance and characterizes EU digital competitiveness), Slovenia is gradually increasing its percentage of Internet users $-73 \%$, with more than $60 \%$ users use the Internet every day, and more than $50 \%$ of Slovenians are aware of basic digital skills in using digital technologies. Slovenia is one of the $10 \mathrm{EU}$ graduates of STEM education. 
sciendo Порівняльна професійна педагогіка 9(4)/2019 Comparative Professional Pedagogy 9(4)/2019

Adoption of the document "DIGITAL SLOVENIA 2020" has begun reform in line with these strategic guidelines for the country for digital society development by 2020 (Strateške usmeritve nadaljnjega uvajanja IKT v slovenske VIZ do leta 2020). The next step was the approval by the Board of the Ministry of Education, Science and Sport of Slovenia of the document "Strategic Guidelines for the Further Introduction of Digital Technologies in Slovenian Institutions of Education by 2020". According to this document, its main goals are: development of didactic materials using digital technologies; supporting the functioning of educational platforms; forming digital literacy and digital competence of all participants in the educational process; digitization of educational institutions, including support for administrative management; e-learning in the field of higher education and adult education and evaluation of digitization (DIGITAL SLOVENIA 2020).

At the state level, the main responsibility for adult education and retraining lies with the Ministry of Education, Science and Sport of Slovenia, which employs a specialized department of higher education and adult education. The formation of digital literacy begins at the school level, where in addition to the 8th grade studing you can choose specialized subjects in digital technologies. Regarding the professional development of teachers and the qualification of professionals in Slovenia, there is a large network of adult education institutions offering digital competency programs and opportunities for participation in national and international digital-oriented training programs. This helps to improve the quality of the educational process and its own professional growth (Põldoja, 2016).

Of particular importance is the experience of European countries that have recently become members of the European Union, such as Lithuania and Estonia.

Foundation of Information Technology for Education was established in Estonia. Its purpose is to provide broad digital education and digital education within the education sector and to provide a strong impetus to the digital literacy and digital competence of educators to ensure high quality education in the country. The Foundation Education Information Technology has initiated the education programs of the education system of Estonia, for example, reforming education on digital literacy for citizens "Education Strategy 2012-2020", IT Academy, digital education and others (Hariduse Infotehnoloogia Sihtasutus, HITSA).

An important issue here is the solution of the problem of forming educating digital competence of teachers for their skillful application of created digital educational materials, digital environment and digital tools for dissemination of the latest pedagogical practices. Thus, in Estonia, teachers are required to take 40-hour digital education training courses in European Computer Rights (ECDL) every 3 years. Teachers' digital competence is assessed on the basis of DigComp 2.0, 2.1, and within the framework of the national DigiMina Estonian project, after which they receive a certificate.

It should be noted that in Lithuania the assessment of teachers' digital competence is also carried out in accordance with ECDL standards, in accordance with teacher training programs based on the Center for School Improvement and the Center for Modern Didactics. Teachers' digital literacy is formed through their participation in international projects aimed at creating online platforms for developing digital competence and improving digital skills in their learning activities. After completing the training course on the project site one can take an online test and determine the level of digital literacy and digital skills in professional and daily life (European Commission, 2019).

The described digital literacy instuments in the EU and Ukraine have their differences. The situation in Ukraine has developed in such a way that in the age of the 
digital economy education and public administration require major reform in the direction of digitalization. The development of digital technologies helps to change the form and methods of professional development of teachers, which in turn increases the level of training of the educational recipients themselves. At the same time, higher and vocational education cannot be reformed in accordance with the requirements of society and the development of digital technologies. The growing number of open online resources for education and training provides educators with opportunities for non-formal learning and ongoing professional development. But there is no systematic state support for this process, so not all teachers have mastered the key professional skills of the modern person. Therefore, it reinforces the need to accelerate the digitalisation of higher and vocational education, and in particular the introduction of new teaching methods and technologies for teachers and students (Kovalchuck, 2017a; 2017b).

At the same time, a large number of Ukraine's population shows the relatively low level of digital literacy required to exist in a digital society. The main problem is the low digitization of infrastructure and remote regions. In order to bridge the digital divide in comparison with the developed EU countries, a set of digital economy measures aimed at new business opportunities and citizens focused on the development of national digital infrastructures was created: mobile and telecommunication infrastructure, digital television infrastructure, radio and technological infrastructure for projects "Internet of Things" (LoRaWan, etc.), computing infrastructure, virtualization and data storage (including cloudy and foggy), cyber security infrastructure, special lysed infrastructures and others. For the development of the digital economy of Ukraine should not be ignored identity and trust infrastructure, open data infrastructure, interoperability infrastructure, blockchain infrastructure, online payment and transaction infrastructure, e-commerce infrastructure and online interaction of business entities (e-contracting, e-invoicing, online lending, smart logistics, etc.), public service infrastructure (e-government), life support infrastructure (medicine, education, public safety, transport, etc.), geoinformation infrastructure, industrial digital infrastructures and others (Cabinet of Ministers of Ukraine, 2018).

\section{CONCLUSIONS}

Digitalization is differently reflected in the national strategy of different countries, but the spread of digital technologies in all aspects of human life requires the state apparatus to immediately increase the level of digital literacy of all segments of the population. And bearing in mind that the active development of digital literacy is closely linked to innovative teaching methods, in order to master digital literacy, the modern educational process must have a sufficiently high level of digital technology.

Further attention is needed to explore the digitalization model of Ukraine's education system in line with current requirements and to learn from the successful experience of developed countries.

\section{REFERENCES}

1. Belshaw, D. (2011). The essential elements of digital literacies. Retrieved from http://digitalliteraci.es/.

2. Country information - Lithuania. European Commission. (2018). Retrieved from https://ec.europa.eu/digital-single-market/en/country-information-lithuania.

3. Digital Agenda of Ukraine - 2020. (2018). Retrieved from http://www.eukraine.org.ua/media/Lviv_Minich_2.pdf. 
sciendo Порівняльна професійна педагогіка 9(4)/2019 Comparative Professional Pedagogy 9(4)/2019

4. DIGITAL SLOVENIA 2020. (2018). Retrieved from http://www.digitalna.si/si/

5. Gere, C. (2008). Digital Culture. London, UK: Reaction Books Ltd.

6. Hariduse Infotehnoloogia Sihtasutus, HITSA. Strategy for 2014-2020. (2014). Retrieved from http://www.hitsa.ee.

7. IT competency Framework for Teacher. (2018). Retrieved from https://www./ yumpu.com/en/document/view/8272114/2-it-competency-framework-for-teachers-kennisnet.

8. Kovalchuck, V. I. (2017a). E-coaching, E-mentoring for lifelong professional development of teachers within the system of post-graduate pedagogical education. Turkish Online Journal of Distance Education-TOJDE, 214-227.

9. Kovalchuk, V. I. (2017b). Tendentsii rozvytku osvity v epokhu informatsiinoho suspilstva. Stratehii intensyfikatsii vyshchoi humanitarnoi osvity v Ukraini ta krainakh YeS, $7-134$.

10. Kovalchuk, V. I. (2018). Zastosuvannia tsyfrovoi pedahohiky v pidhotovtsi maibutnikh fakhivtsiv sfery pidpryiemnytstva. Molodyi vchenyi, 5, 523-526.

11. On Approval of the Concept for the Development of the Digital Economy and Society of Ukraine for 2018-2020 and approval of the plan of measures for its implementation (Cabinet of Ministers of Ukraine). No. 67/2018. (2018).

12. Ons onderwijs 2032. Advisory Report. (2016). Retrieved from http://onsonderwijs/ 2032.n1/wpcontent/uploads/2016/04/160412Eindadvies_Onderwijs2032_UK.pdf.

13. Põldoja, H. (2016). The Structure and Components for the Open Education Ecosystem Constructive Design Research of Online Learning Tools, doctoral dissertation, Aalto University publication series Doctoral dissertations. Retrieved from https://aaltodoc.aalto.fi/ bitstream/handle/123456789/23535/isbn9789526069937.pdf? sequence $=1$ \&isAllo wed $=\mathrm{y}$.

14. Stommel, J. (2014). Critical Digital Pedagogy: a definition. Hybrid Pedagogy. A digital journal of learning, teaching and technology. Retrieved from https:// hybridpedagogy.org/critical-digital-pedagogy-definition/.

15. Strateške usmeritve nadaljnjega uvajanja IKT v slovenske VIZ do leta 2020. (2016). Retrieved from http://www.mizs.gov.si/fileadmin/mizs.gov.si/pageuploads/ StrateskeUsmeritveNadaljnjegaUvajanjaIKT1_2016.pdf.

16. Summary of the Education and Adoption Act 2017. UK Parliament official site. (2017). Retrieved from https://services.parliament.uk/bills/2016-17/highereducatio/ nandresearch.html.

17. The European Commission. (2017). Eastern Partnership - Focusing on key priorities and concrete achievements. Retrieved from https://eeas.europa.eu/sites/ eeas/files/swd_2017_300_f1_joint_staff_working_paper_en_v5_p1_940530.pdf. 